\title{
小規模清酒製造場における 製造改革と技術の継承
}

本誌第 89 巻 7,9 月号で，製造規模別の新酒造システムを紹介した。

今回は製造規模 $140 \mathrm{k} \boldsymbol{l}$ という小規模酒造場で，清酒製造技術を継承しつつ，従来とは異なった製造システム で意欲的に酒造りに取り組んでいる若い後継者の生の声である。若い後継者の方々へのエールとなれば幸いであ る。

保坂大二郎

\section{1. はじめに}

当蔵元は茨城県の西部, 鬼怒川の流れる「結城つむ ぎ」で有名な結城市にある。創業は江戸末期（慶応年 間）で, 越後商人の保坂勇吉がここに蔵を建て, 銘柄を 「武勇」とし現在に至っている。平成 5 BY の製造数量 は $140 \mathrm{k} l$ で, その内訳は普通酒 $50 \mathrm{k} l$, 特定名称酒 90 $\mathrm{k} l$ となっている。

社員一同, “納得のいく酒造り”をモットーに今期も 10 月初旬に洗付作業に入り, 来年の 5 月下旬までの 3 季醸造体制で稼働する予定である。

\section{2. 通年体制への移行}

社会的構造の変化による季節労働者の高年㛔化・減少 化は年々深刻さを増しており, 切迫した問題として表面 化してきている。実際, 当蔵でも季節雇用の蔵人による 酒造りは平成元酒造年度が最後となり, 平成 2 年の春の 時点で次の年には蔵人が揃わないという状況におちいっ た。

このままでいくと, 酒を造れない蔵元になってしま う。酒の造れる蔵元として生き残れるためには改革をし なけれぱと思い, 平成 2 年の春, 酒造りが終わると同時 に大改革を始めた。杜氏一人だけは今まで通り来てくれ るといらので, 社長である父と私とで相談し, 私も酒造

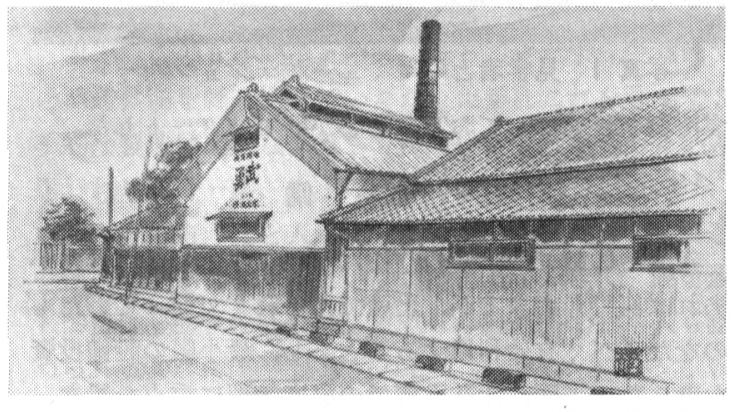

りに参加した上で, 地元の従業員の年間雇用体制, 3 季 醇造体制の導入を試みた。幸い20 代の地元男子従業員 3 名を確保することができた。

“私も製造に参加する”と書いたが，これは小規模酒 蔵では絶対必要であり, 杜氏以外に酒造りのできるスタ ッフがいない状沉では, 自らが酒造りに携わり, 若いス タッフと一緒に仕事をしていくことが，一番重要なこと であると思う。60 歳以上の人が 20 代の人に酒造りを教 えるのには, 年齢的にも経験的にも中間層である人が両 方の言い分を聞き, うまくコミュニケーションをはから ないと円滑にいかないからである。

\section{3. 新体制での問題点}

酒造の労務面では週 1 本, もしくは 2 本仕达みとした ため, ペースがゆっくりなので, あまり大きな問題点は なかった。やはり問題は 20 代の, 酒の造り方を全く知 らない従業員に, どうやって酒造技術を教えるか, であ った。また， 3 季醸造体制であっても冬期だけは従前か らの杜氏 1 人は勤務しているので, 杜氏と若い従業員と のコミュニケーションが一番の問題であった。さらに私 と杜氏 2 人とも, それまでに 3 季醸造の体験がなかった ため, 頭の中では分かっていても, 実際に外気温の高い 時期に酒造りが可能なのかは半信半疑であった。とりあ えず有害微生物による污染箇所を少なくし, 蔵内を絶え

Improvement of Brewing Systems and Succession of Brewing Technique at the Small Sake Brewery

Daijiro HoSAKA (Hosaka Sake Brewery) 


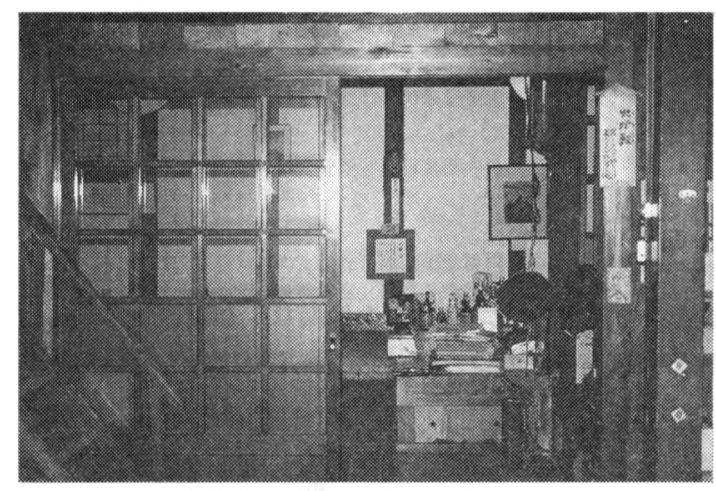

写真 1 見学者とのコミュニケーションルーム

ず清潔な状態にしておこうと心がけてスタートした。

\section{4. 設 備}

新酒造体制での設備の整備については，資金に余裕が あれば何でもできるが，当蔵ではそれまで使っていたも のをなるべく有効利用することとし, 最小限の設備投資 を考えた。当面, 仕込み蔵での温度管理に重点を置き, 土蔵の内側の天井部分を断熱材で覆い, 空調設備を整え た。以前から仕込みタンク冷却用の冷水配管はしてあっ たので，それらには何も手を加えずに済んだ。当蔵で は, 第 1 図のように仕込み蔵の中に放冷機, 圧搾機を設 置している。その点では一つの蔵内空調設備によって, 蒸米の放冷, 仕込み蔵の空調, 圧搾機周辺の空調が同時 にでき，大変助かった。

\section{5. 人材育成}

新酒造体制に移行した当初, 酒造従業員は杜氏以外す ベて 20 歳代, 私を除いて酒造経験者ゼロであった。そ れゆ光週一回は酒造のレクチャーを私が約 1 時間するこ とにした。また, 各種品評会にも必ず出席し, きき酒を 体験させたり，酒造期間中でも近くの蔵元に見学に行 き, 当蔵以外の酒造りをなるべく多く勉強させた。他社 の製品も絶えず調達して, きき酒の勉強会を行った。

ここで一番大切なのは, いかに酒に興味を持たせる か, に尽きる。微生物の話から酒の品質設計, 消費者動 向などいろいろな観点より, 酒を見つめてもらった。徐

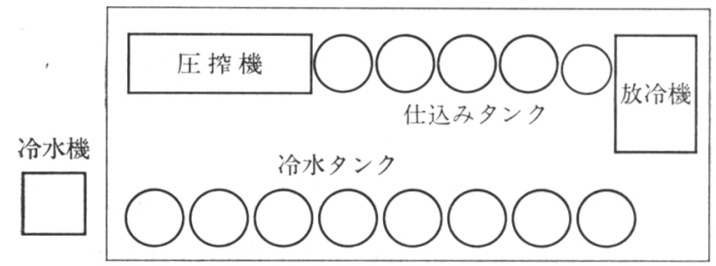

第 1 図 仕込蔵見取図

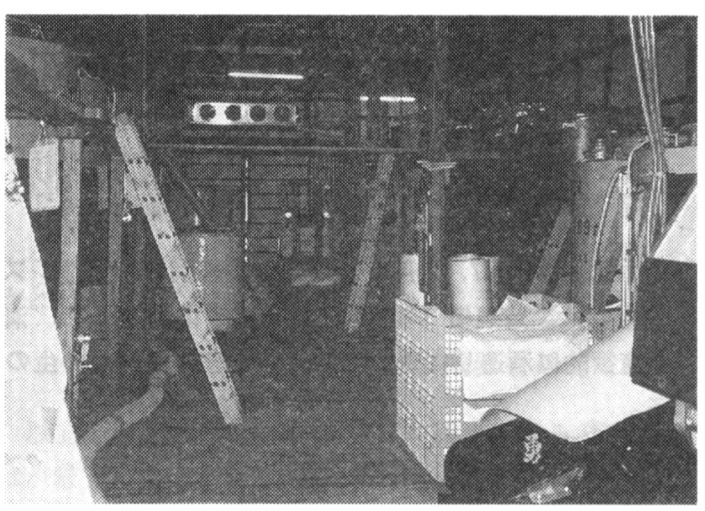

写真 2 仕込蔵内部

々に彼らにいろいろな疑問点が出てくるので, それらを 私をはし゚め, 杜氏や社長に質問させるようにした。聞か れた方も中途半端な答えはできないので, それでおのず と良いコミュニケーションがはかれることになった。仕 込みは週 1 本もしくは 2 本なので時間には余裕があっ た。このよらな状態の中で様々なことを考光, 疑問を持 ってもらうことにした。これが従来通りの半仕舞, 日仕 舞では毎日の仕事に追われてしまい, 考える余裕などは 出てこない。私は週 1 本もしくは 1.5 本ぐらいの仕込み 方法が理想的た゚と思っている。また週 1 本仕込みは, も ろみを上槽した時点で絶えず酒質をチェックでき, 次の 仕込みに何をどう変えれば目標としている酒質に近づく かをすぐ判断して実行に移せるという長所がある。

以上のよらな人材育成のための努力は今も続けてお り, 幸いにも当初の従業員が現在もスタッフとして頑張 ってくれている。

\section{6. 新体制での酒造方法}

現在の蔵人の構成は, 60 代の杜氏 (季節雇用), 私と 年間雇用の 20 代の男子従業員 2 名, 女子従業員 1 名で ある。酒造期間中は, 午前中だけ製品部の女子パート 2 人に酒粕処理をしてもらっている。勤務は午前 8 時出 社, 午後 5 時退社を基本としている。

蒸しは和鉒方式で, 昨年度の造りまでは中に人が入 り, 人力で蒸米を掘っていたが, 今年度の造りから和鉒 方式はそのままで, 蒸米作業をホイスト (クレーン)を 使った釣り上げ方式に変えた。製憗法は天幕式と箱䅗式 を併用している。当然, 夜間の仕事が出てくるので, 週 に 3 ～ 4 日は 1 人ずつ交替で仕舞仕事等をしてから帰宅 してもらっている。酒母は高温糖化法を用い, 8〜9日 目の使用。仕込みは総米 $1,800 \mathrm{~kg}$ が標準で, 添・仲・留 の 3 段仕込みで週に $1 \sim 2$ 本としている（第 1 表，第 2 表参照)。上槽は枠の開閉装置が着いた自動もろみ圧搾 
第 1 表 週 1 本仕込みでの仩込み予定表

\begin{tabular}{|l|l|l|l|l|l|l|l|l|l|l|l|l|l|}
\hline 日 & 月 & 火 & 水 & 木 & 金 & 土 & 日 & 月 & 火 & 水 & 木 & 金 & 土 \\
\hline & & 酛 & 添 & & 仲 & 留 & & & 酛 & 添 & & 仲 & 留 \\
\hline
\end{tabular}

第 2 表 週 1 本仕込みでの洗米予定表

\begin{tabular}{|c|c|c|c|c|c|c|c|c|c|c|c|c|c|}
\hline 日 & 月 & 火 & 水 & 木 & 金 & 土 & 日 & 月 & 火 & 水 & 木 & 金 & 土 \\
\hline & & & 酛 添 & & & & & 酛 仲 & 添 留 & & 仲 & 留 & \\
\hline & & & 麴 & & & & & 掛 麳 & 掛 麥米 & & 掛 & 掛 & \\
\hline & & & 米米 & & & & & 米米 & 米米 & & 米 & 米 & \\
\hline & & & 洗 洗 & & & & & 洗 洗 & 洗 洗 & & 洗 & 洗 & \\
\hline & & & 米米 & & & & & 米米 & 米米 & & 米 & 米 & \\
\hline
\end{tabular}

機を使用している。

酒造期間中は週休 1 日（主に日曜日）制をとり，正月 は 4 〜 5 日間休みをとる。非酒造期間は週休 2 日制, か つ交替で 3 週間のリフレッシュ休暇がとれるよらにして いる。

\section{7. 営業面での対処方法}

当蔵のような小規模製造場では自らが酒を造り，自ら が販売もしていかなければならない。両方をらまくでき れば理想的であるが，当然そうはいかない。私は現在，

造りの時期の約 9 力月間は製造に集中して一切の営業活
動をせず，製造の終わった夏の時期にその年の酒造りの 話を中心とした営業活動なるものを行っている。

これからは小さな酒蔵が，ぞういら小売店とどのよう に生き残っていくかを考光なければならない。そのため にメーカーとしての体制, 姿勢をしっかり小売店に伝え て, その上での営業活動が必要だと思う。私はメーカー としてのプロ意識が今後ますます問われるのではないか と思っている。

\section{8. ま と め}

以上, この 5 年間添どの間にやってきた小規模酒蔵で の酒造体制を紹介させていただいたが，これを読んで3 季的な製造はそんな難しくはないと思った方も多いと 思われる。今一番, 中小の酒蔵に求められているのは, メーカーの方向性と人づくりだと思う。私自身も「酒造 りは人づくり」であるというこの言葉が好きで, 酒を通 して自分も磨き, 社会にも貢献し, 結果的飞酒も人も認 められるように日々研鑽努力していきたいと思ってい る。

今回は当方の諸事情により概略だけの紹介になってし まったが，夏期には同業者の方々との意見交換もしたい と思って抢り，小さな酒蔵ではあるが酒潐わって拈ら れる皆様共々，日本酒といら文化を大切にしていきたい と考光ている。

<武勇醸造元・保坂酒造店 $>$ 